\title{
Salarissen en competenties van MBO-BOL gediplomeerden: Feiten en cijfers
}

Citation for published version (APA):

Verhagen, A. M. C., \& Meng, C. M. (2014). Salarissen en competenties van MBO-BOL gediplomeerden: Feiten en cijfers. ROA. ROA Fact Sheets No. 001 https://doi.org/10.26481/umarof.2014001

Document status and date:

Published: 01/01/2014

DOI:

10.26481/umarof.2014001

Document Version:

Publisher's PDF, also known as Version of record

\section{Please check the document version of this publication:}

- A submitted manuscript is the version of the article upon submission and before peer-review. There can be important differences between the submitted version and the official published version of record.

People interested in the research are advised to contact the author for the final version of the publication, or visit the DOI to the publisher's website.

- The final author version and the galley proof are versions of the publication after peer review.

- The final published version features the final layout of the paper including the volume, issue and page numbers.

Link to publication

\footnotetext{
General rights rights.

- You may freely distribute the URL identifying the publication in the public portal. please follow below link for the End User Agreement:

www.umlib.nl/taverne-license

Take down policy

If you believe that this document breaches copyright please contact us at:

repository@maastrichtuniversity.nl

providing details and we will investigate your claim.
}

Copyright and moral rights for the publications made accessible in the public portal are retained by the authors and/or other copyright owners and it is a condition of accessing publications that users recognise and abide by the legal requirements associated with these

- Users may download and print one copy of any publication from the public portal for the purpose of private study or research.

- You may not further distribute the material or use it for any profit-making activity or commercial gain

If the publication is distributed under the terms of Article $25 \mathrm{fa}$ of the Dutch Copyright Act, indicated by the "Taverne" license above, 


\section{Salarissen en competenties van $\mathrm{MBO}-\mathrm{BOL}$ gediplomeerden: Feiten en cijfers}

\section{ROA Fact Sheet}

\section{ROA-F-2014/1}

Researchcentrum voor Onderwijs en Arbeidsmarkt | ROA Research Centre For Education and the Labour Market / ROA 


\section{Inleiding}

Een risico dat de afgelopen jaren steeds groter wordt is dat verregaande automatisering van met name taken in middelbare beroepen leidt tot een dalende vraag naar MBO opgeleiden. In dit factsheet wordt onderzocht of de toenemende automatisering van taken in met name middelbare beroepen terug te zien is in veranderingen in het relatieve belang van bepaalde competenties van MBO-gediplomeerden voor het goed uitoefenen van hun functies. Ook bestuderen we of de waarde die werkgevers hechten aan de competenties van recent MBO-gediplomeerden door de jaren heen is veranderd, door te kijken naar de relatieve veranderingen in het gemiddelde bruto uurloon.

Voor het Factsheet worden ten eerste data afkomstig van de BVE-Monitor van het Researchcentrum voor Onderwijs en Arbeidsmarkt (ROA) geanalyseerd.' De gegevens hebben voor paragraaf 2 over de competenties betrekking op de metingen die in de jaren 1999 (gediplomeerde schoolverlaters van het schooljaar 1997-1998) tot en met 2010 (gediplomeerde schoolverlaters van het schooljaar 2008-2009) plaatsvonden.

Voor paragraaf 3 over de bruto uurlonen hebben de gegevens betrekking op de metingen 1996 (gediplomeerde schoolverlaters van het schooljaar 1994-1995) tot en met 2013 (gediplomeerde schoolverlaters van het schooljaar 2011-2013). De analyses worden daarbij toegespitst op de gediplomeerden van het MBO-BOL. Daarnaast worden in deze paragraaf gegevens afkomstig van de HBO-Monitor geanalyseerd. Deze gegevens hebben eveneens op dezelfde periode betrekking. De HBO-Monitor wordt vooral ingezet om de gegevens van de MBO-BOL niveau 4 gediplomeerden in een context te plaatsen. Daarom spitst de analyse van de HBO-Monitor data zich toe op de afgestudeerden van voltijd Bachelor HBO opleidingen.

\section{Het belang van competenties in het werk van MBO-BOL gediplomeerden}

De BVE-Monitor vragenlijst kent in de periode vanaf $1999^{2}$ een uitgebreide lijst van competenties. Respondenten worden daarbij gevraagd om voor verschillende items op een 5-punt Likert schaal aan te geven in hoeverre het item van belang is voor goed uitoefenen van de huidige functie. Een discussie van alle items afzonderlijk is buiten de scoop van dit Factsheet. Daarom zijn de items op basis van cluster analyses gereduceerd tot vier clusters van één vakspecifieke en drie generieke competenties die nader geanalyseerd zullen worden (zie tekstbox 2.1). Er is gecontroleerd dat deze clusters voldoende interne betrouwbaarheid hebben.

. Voor meer informatie over de BVE-Monitor, zie http://roa.nl/SIS/index.htm. 2. Vanaf meting 2011 is de vraag enigszins veranderd, waardoor de resultaten van de metingen $2011 \mathrm{t} / \mathrm{m} 2013$ niet in de analyses verwerkt kunnen worden.
Tekstbox 2.1

Clusters van competenties met onderliggende items
Vakkennis
- Vakkennis
- Toepassen van kennis en technieken in de praktijk

Persoonlijkheid

- Zelfstandigheid

- Initiatief, creativiteit

- Aanpassingsvermogen

- Nauwkeurigheid, zorgvuldigheid

\section{Basis generieke competenties}

- Schrijfvaardigheid

- Spreekvaardigheid

\author{
Advanced generieke competenties (21st century skills) \\ - Inzicht in informatie- \& communicatietechnologie (incl. \\ computergebruik) \\ - Overdragen van kennis \\ - Plannen, coördineren, organiseren van activiteiten \\ - Oplossen van problemen \\ - Contactuele vaardigheden \\ - Werken in teamverband/samenwerken
}

Ongeveer anderhalf jaar na afstuderen geven de MBO-BOL gediplomeerden die werkzaam zijn structureel aan dat de competentie die we hier 'persoonlijkheid' noemen het belangrijkst is voor het goed uitoefenen van hun functie (zie figuur 2.1). Het belang van deze competentie is sinds 2002 zo'n 4\% lager dan dat het in de periode 1999-2001 was (een daling van 4.5 naar 4.3 op de 5-punt Likert schaal).

De basis generieke competenties worden structureel het minst belangrijk gevonden, en de absolute belang-scores blijven door de jaren heen vrij constant. Toch is de spreiding van deze competentie relatief groot, wat aangeeft dat het absolute en relatieve belang van deze competentie wel eens zou kunnen verschillen als we gaan uitsplitsen naar niveau of sector.

Vakkennis en advanced generieke competenties worden structureel minder belangrijk gevonden dan dat van 'persoonlijkheid' voor het goed uitoefenen van de functie, maar belangrijker dan de basis generieke competenties. Zowel het belang van vakkennis als dat van advanced generieke competenties blijft door de jaren heen redelijk stabiel (verschillen van maximaal zo'n 3\%), maar toch is in de figuur al te zien dat vakkennis sinds 2005 relatief iets belangrijker wordt gevonden dan advanced generieke competenties: er is namelijk een afstand tussen de twee trendlijnen ontstaan. Ook kunnen we zien dat de afstand tussen de trendlijnen van het belang van 'persoonlijkheid' en vakkennis steeds kleiner wordt.

Deze veranderingen in het relatieve belang van vakkennis zijn grafisch weergegeven in figuur 2.2, waar de nullijn het belang van vakkennis weergeeft. De figuur laat zien hoeveel procent het belang van elke competentie verschilt van het belang van vakkennis. In figuur 2.1 zagen we bijvoorbeeld dat 
in 1999 het belang van vakkennis voor het goed uitoefenen van de functie gewaardeerd werd op 4.12, en dat het belang van de basis generieke competenties een score had van 3.67. Het verschil is 0.45 punten, wat neerkomt op een procentueel verschil van 10.9\%: In 1999 werd vakkennis $11 \%$ belangrijker gevonden voor het uitoefenen van de functie dan basis generieke vaardigheden.

Figuur 2.1

Ontwikkeling van het belang van competenties voor het goed uitoe fenen van de huidige functie van MBO-BOL gediplomeerden, ongeveer 1.5 jaar na afstuderen*$$
5
$$

4

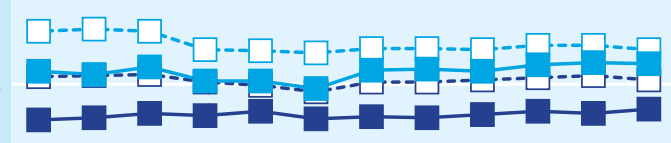

3

2

1199920002001200220032004200520062007200820092010

-- $\square$ - - Persoonlijkheid -- $\square$-- Advanced generiek

-Vakkennis Basis generiek

*(1=zeer onbelangrijk <-> 5=zeer belangrijk)

Bron: SIS (ROA), 1999-2010

\section{Figuur 2.2}

Het relatieve belang van vakkennis voor het goed uitoefenen van de huidige functie van MBO-BOL gediplomeerden, ongeveer 1.5 jaar na afstuderen (\%)

20

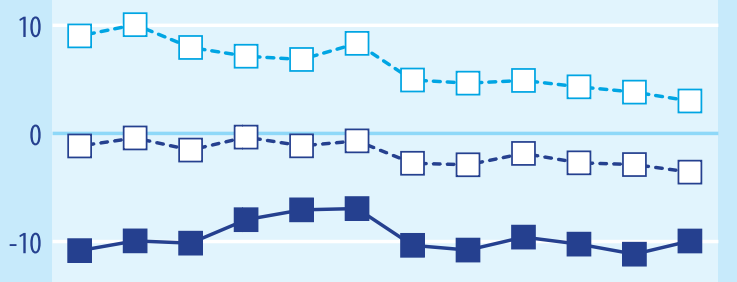

$-20$

199920002001200220032004200520062007200820092010

-- $\square$-- Persoonlijkheid

-- $\square$--Advanced generiek

- Basis generiek

Bron: SIS (ROA), 1999-2010

In de figuur is duidelijk te zien dat het verschil tussen het belang van vakkennis en advanced generieke competenties in de periode 1999-2004 nihil is, maar dat vakkennis sinds 2005 gemiddeld zo'n 3-4\% belangrijker wordt gevonden voor het goed uitoefenen van de functie dan advanced generieke competenties. Vakkennis wordt doorgaans zo'n 11\% belangrijker gevonden dan basis generieke competenties, behalve in de periode 2002-2004, waar het zo'n 7\% belangrijker gevonden wordt dan basis generieke competenties. Tot slot maakt de figuur duidelijk dat hoewel 'persoonlijkheid' ook in 2010 nog altijd belangrijker wordt gevonden dan vakkennis voor het goed uitoefenen van de functie, het relatieve verschil constant afneemt, van zo'n 10\% in 1999 tot zo'n 3\% in 2010.

\section{Verschillen per niveau}

Net als voor het totale MBO-BOL, geldt voor alle vier de niveaus dat 'persoonlijkheid' structureel het belangrijkst en basis generieke competenties structureel het minst belangrijk worden gevonden voor het goed uitoefenen van de functie. Ook zien we op alle niveaus dat het verschil tussen het belang van vakkennis en het belang van 'persoonlijkheid' door de jaren heen steeds kleiner wordt. In niveau 4 zien we een vergelijkbare trend van het relatieve belang van vakkennis ten opzichte van advanced generieke competenties: in de periode 1999-2004 is er nauwelijks verschil in belang tussen deze competenties, maar vanaf 2005 is vakkennis relatief belangrijker dan advanced generieke competenties. In niveaus 2 en 3 daarentegen, wordt vakkennis structureel zo'n $5 \%$ belangrijker gevonden dan advanced generieke competenties. Ook valt binnen niveau 3 op dat het verschil in belang tussen 'persoonlijkheid' en vakkennis kleiner is dan voor het totale MBO-BOL. Binnen MBO-BOL niveau 1 hebben de trends van het belang van competenties een te grillig verloop om hier algemene uitspraken over te kunnen doen. Dit zal te maken hebben met het relatief kleine aantal $\mathrm{MBO}-\mathrm{BOL}$ niveau 1 gediplomeerden dat werkzaam is.

\section{Verschillen per opleidingssector}

Hoewel de trends van de absolute belang-scores van de competenties er voor alle opleidingssectoren vergelijkbaar uitzien ('persoonlijkheid' is structureel het belangrijkst, basis generieke competenties het minst belangrijk), zijn er wel verschillen te zien tussen opleidingssectoren in het relatieve belang van vakkennis. Deze verschillen worden hieronder besproken. De overeenkomst, echter, zijn dat het verschil tussen het belang van vakkennis en het belang van 'persoonlijkheid' steeds verder afneemt en dat dit zowel komt door een absolute afname van het belang van 'persoonlijkheid' als een absolute toename van het belang van vakkennis.

Vergeleken met de andere sectoren lijkt vakkennis voor de economen het minst belangrijk te zijn voor het goed uitoefenen van de huidige functie. Dit heeft er waarschijnlijk mee te maken dat gediplomeerden van MBO Economie relatief vaak buiten hun eigen studierichting werkzaam zijn. Zo is Economie de enige opleidingssector waar advanced generieke competenties in de gehele periode 1999-2010 structureel belangrijker worden gevonden dan vakkennis (zie figuur 2.3). Toch zien we ook hier dat vanaf 2005 het relatieve belang van advanced generieke competenties ten opzichte van vakkennis afneemt. Ook het relatieve belang van 'persoonlijkheid' ten opzichte van vakkennis is structureel hoger dan voor het MBO-BOL totaal. Doorgaans worden alleen de basis generieke competenties belangrijker gevonden dan vakkennis 
door de werkzame gediplomeerden van de sector Economie. Maar hoewel vakkennis voor het MBO-BOL totaal zo'n $11 \%$ belangrijker werd gevonden dan basis generieke competenties, is dit binnen de sector Economie doorgaans slechts zo'n $3 \%$. Binnen deze sector werden basis generieke competenties in de periode 2002-2004 zelfs zo'n 2\% belangrijker gevonden dan vakkennis.

\section{Figuur 2.3}

Het relatieve belang van vakkennis voor het goed uitoefenen van de huidige functie van MBO-BOL gediplomeerden van de sector Economie, ongeveer 1.5 jaar na afstuderen (\%)

20

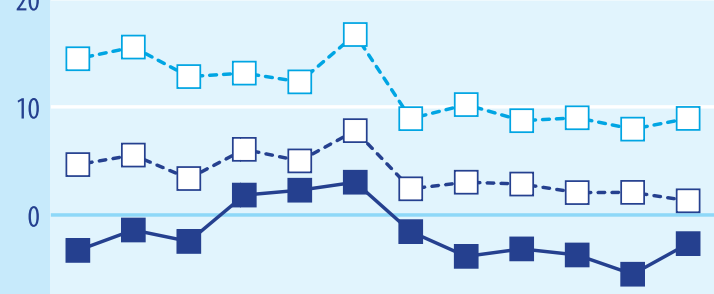

$-10$

$-20$

199920002001200220032004200520062007200820092010

-- $\square$-- Persoonlijkheid

-- $\square$--Advanced generiek

- Basis generiek

Bron: SIS (ROA), 1999-2010

Ook binnen de opleidingssector Gedrag \& Maatschappij is het verschil tussen het belang van vakkennis en het belang van basis generieke competenties met zo'n $6 \%$ laag vergeleken met het MBO-BOL totaal. Dit komt met name doordat het belang van basis generieke competenties in absolute waarden vrij hoog ligt (rond de 4.0, in plaats van rond de 3.7 voor MBO-BOL totaal). Verder zien we binnen deze sector een min of meer vergelijkbaar beeld als voor het MBO-BOL totaal. In andere woorden wordt de opleidingssector Gedrag \& Maatschappij met name gekenmerkt door een relatief laag belang van basis generieke competenties; zowel in absolute waarden, als relatief ten opzichte van vakkennis.

Vakkennis is relatief het belangrijkst voor werkzame gediplomeerden van de sectoren Landbouw, Techniek en Gezondheidszorg. Het verschil tussen basis generieke competenties en vakkennis is binnen deze opleidingssectoren relatief hoog: rond de 15 à $17 \%$. Ook wordt binnen deze sectoren vakkennis structureel zo'n $5 \%$ belangrijker gevonden dan advanced generieke competenties (voor het MBO-BOL totaal en voor de sector Gedrag \& Maatschappij wordt vakkennis pas vanaf 2005 belangrijker gevonden dan advanced generieke competenties). Vakkennis is relatief het belangrijkst voor werkzame gediplomeerden van de sector Gezondheidszorg, omdat binnen deze sector ook het verschil met 'persoonlijkheid' marginaal is (zie figuur 2.4).
Figuur 2.4

Het relatieve belang van vakkennis voor het goed uitoefenen van de huidige functie van MBO-BOL gediplomeerden van de sector Gezondheidszorg, ongeveer 1.5 jaar na afstuderen (\%)

20

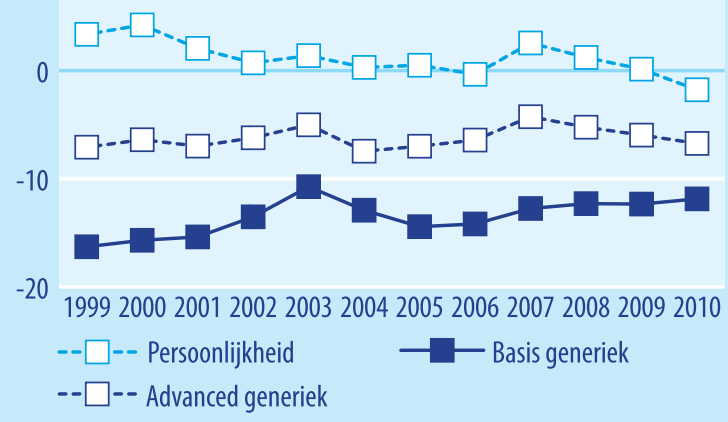

Bron: SIS (ROA), 1999-2010

\section{Het salaris van MBO-BOL en $\mathrm{HBO}$ Bachelor gediplomeerden}

In economische termen is het bruto uurloon een belangrijke indicator van de waarde die werkgevers hechten aan de competenties van de recent gediplomeerden. Figuur 3.1 biedt daarom een grafische weergave van de ontwikkeling van de bruto uurlonen van MBO-BOL en HBO Bachelor (voltijd) gediplomeerden. Daarbij is gecorrigeerd voor inflatie.

In de figuur is duidelijk te zien dat een hoger opleidingsniveau doorgaans gepaard gaat met een hoger gemiddeld bruto uurloon. Ook is te zien dat de gemiddelde bruto uurlonen van MBO-BOL niveau 3 en 4 gediplomeerden, ondanks conjuncturele pieken en dalen, langzaam aan het stijgen zijn. Gecorrigeerd voor inflatie zijn hun uurlonen in 2013 gemiddeld zo'n €0.90 hoger dan dat ze in 1996 waren.

De bruto uurlonen van de gediplomeerden van $\mathrm{MBO}-\mathrm{BOL}$ niveau 4 en $\mathrm{HBO}$ Bachelor zijn het meest gevoelig voor de conjunctuur. Het gemiddelde bruto uurloon van gediplomeerden van $\mathrm{MBO}-\mathrm{BOL}$ niveau 3 is wat minder conjunctuur gevoelig, omdat zij in hun bruto uurloon vrij weinig van de recessie in de periode 2001-2005 lijken te hebben gemerkt. De ontwikkeling van het gemiddelde bruto uurloon van werkzame MBO-BOL niveau 2 gediplomeerden lijkt - na correctie voor inflatie - over het algemeen vrij stabiel, maar ook hier zien we de laatste jaren een constante daling in het uurloon. Het gemiddelde bruto uurloon van MBO-BOL niveau 1 gediplomeerden kent een vrij grillig verloop. Dit heeft waarschijnlijk met het ontbreken van een startkwalificatie te maken: het aandeel werkenden is vrij klein, en degenen die wel werken doen dat tegen de verwachting in en zijn daardoor een vreemde eend in de bijt. Toch lijkt er ondanks het grillige verloop van de trend een daling in het gemiddelde bruto uurloon van werkzame MBO-BOL niveau 1 gediplomeerden waarneembaar. 
Figuur 3.1

Bruto uurlonen (inflatie gecorrigeerd) van werkzame $\mathrm{MBO}-\mathrm{BOL}$ en HBO Bachelor gediplomeerden, ongeveer 1.5 jaar na afstuderen, gemiddeldes per opleidingsniveau.

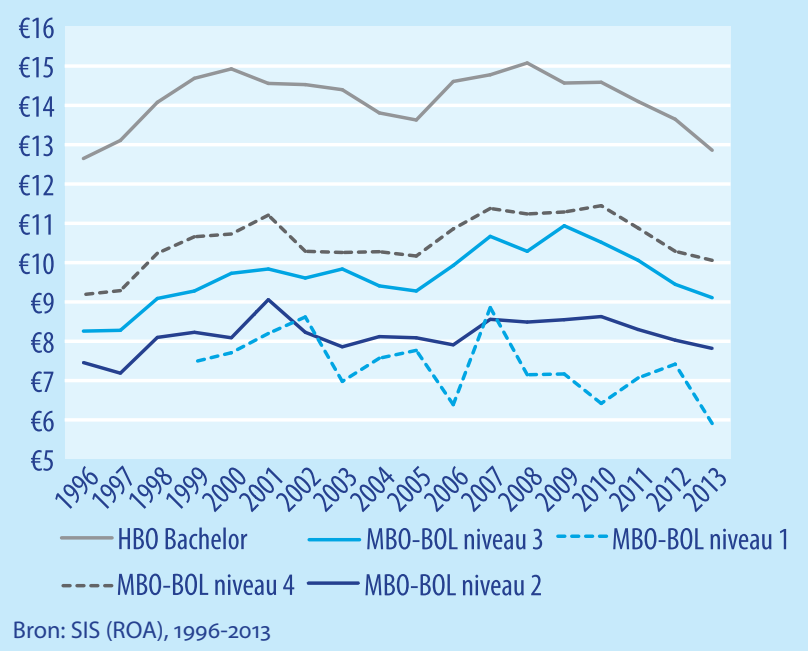

In figuur 3.1 is al te zien dat de afstand tussen de gemiddelde bruto uurlonen van gediplomeerden van de verschillende niveaus aan verandering onderhevig is. Om deze verschillen tussen niveaus beter inzichtelijk te maken, is berekend hoeveel procent de gemiddelde bruto uurlonen verschillen van het bruto uurloon van MBO-BOL niveau 4 gediplomeerden (zie figuur 3.2). Dat betekent dat de nullijn het gemiddelde bruto uurloon van $\mathrm{MBO}-\mathrm{BOL}$ niveau 4 gediplomeerden representeert.

\section{Figuur 3.2}

Relatieve hoogte van het gemiddelde bruto uurloon van werkzame $\mathrm{MBO}-\mathrm{BOL}$ niveau 4 gediplomeerden (inflatie gecorrigeerd), ongeveer 1.5 jaar na afstuderen (\%)

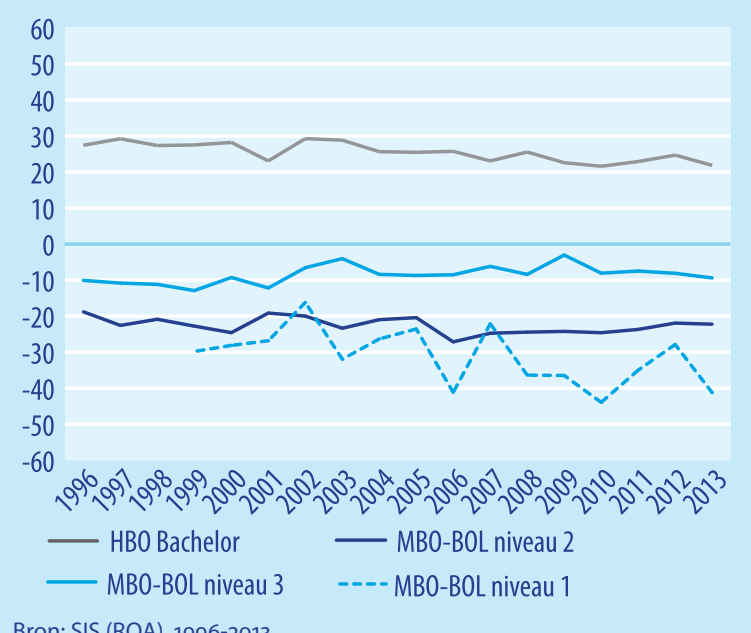

Bron: SIS (ROA), 1996-2013

Hoewel het gemiddelde bruto uurloon van HBO Bachelor gediplomeerden structureel hoger is dan dat van MBO-BOL niveau 4 gediplomeerden, neemt het relatieve verschil geleidelijk af, van $38 \%$ in 1996 naar $28 \%$ in 2013. Dit komt met name door de geleidelijke stijging van het bruto uurloon van MBO-BOL niveau 4 gediplomeerden.
Het verschil tussen het bruto uurloon van $\mathrm{MBO}-\mathrm{BOL}$ niveau 4 ten opzichte van niveau 2 en 3 gediplomeerden is in de periode 1999-2013 over het algemeen redelijk constant. MBO-BOL niveau 3 gediplomeerden verdienen zo'n 10\% minder, en MBO-BOL niveau 2 gediplomeerden zo'n $22 \%$ minder dan $\mathrm{MBO}-\mathrm{BOL}$ niveau 4 gediplomeerden. Toch zien we dat het verschil tussen niveau 3 en 4 in de jaren 2002, 2003 en 2009 plots iets kleiner is dan in andere jaren. Overigens wordt het verschil tussen niveau 2 en 3 geleidelijk aan iets groter (zie bijlage **). Deze dalende trend wordt echter onderbroken in tijden waarin het slecht gaat met de economie.

\section{Verschillen per opleidingssector}

In MBO-BOL zijn het de gediplomeerden van de opleidingssectoren Landbouw en Economie die doorgaans een relatief laag bruto uurloon hebben. Hoewel deze sectoren ook in het HBO een relatief laag bruto uurloon hebben, zijn het op dit opleidingsniveau de gediplomeerden van de sector Taal\&Cultuur die er wat betreft het bruto uurloon doorgaans het slechtst vanaf komen. Sinds 2006 is hun gemiddelde bruto uurloon zelfs gekelderd van $€ 13,11$ naar $€ 9,43$ in 2013 . Dat is minder dan de gemiddelde $\mathrm{MBO}-\mathrm{BO}$ niveau 4 gediplomeerde in dat jaar verdiende $(€ 10,05)$.

Binnen de groep gediplomeerden van de sector Landbouw zien we dat het relatieve verschil in het bruto uurloon tussen $\mathrm{MBO}-\mathrm{BOL}$ niveau 4 en $\mathrm{HBO}$ gediplomeerden geleidelijk toeneemt van $33 \%$ in 1996 tot $43 \%$ in 2013 . Eerder zagen we dat het verschil in bruto uurloon tussen deze twee opleidingsniveaus in deze periode juist was afgenomen. Ook valt binnen deze sector op dat het relatieve verschil in bruto uurloon tussen MBO-BOL niveau 4 en 3 met zo'n 20\% groot is vergeleken met het totaal (zo'n 10\%). Hetzelfde geldt voor het relatieve verschil tussen MBO-BOL niveau 4 en 2 (zo'n $30-40 \%$ voor gediplomeerden van Landbouw in plaats van zo'n $20-25 \%$ voor het totaal).

Hoewel gediplomeerden van de sector Economie doorgaans een wat lager dan gemiddeld bruto uurloon hebben, zijn binnen deze sector de verschillen tussen de niveaus redelijk vergelijkbaar met het totaal. Ook voor gediplomeerden van de Technische sector zijn de relatieve verschillen tussen de niveaus vergelijkbaar met het totaal. Ook in absolute termen verdienen zij ongeveer gemiddeld.

Binnen de sector Gedrag \& Maatschappij (alleen MBO-BOL niveau 3 en 4 en HBO Bachelor) zijn de verschillen in bruto uurloon tussen de opleidingsniveaus relatief klein. Het verschil tussen HBO en MBO-BOL niveau 4 is zo'n $35 \%$ in 1996 tot zo'n $23 \%$ in 2013. Het gemiddelde bruto uurloon van MBO-BOL niveau 3 gediplomeerden is zo'n 10\% (in 2003) tot zo'n 5\% (2013) lager dan voor MBO-BOL niveau 4 gediplomeerden.

Gediplomeerden van de sector Gezondheidszorg hebben op alle niveaus doorgaans het hoogste gemiddelde bruto uurloon. Bovendien zijn hun uurlonen in de periode 1996-2013 geleidelijk gestegen. Tussen de niveaus zijn de verschillen door de jaren heen echter redelijk vergelijkbaar met het totaal. 


\section{Conclusies}

Op basis van dit Factsheet kan een drietal conclusies getrokken worden met betrekking tot het belang van competenties:

- De competentie 'persoonlijkheid' (zelfstandigheid, initiatief, creativiteit, aanpassingsvermogen en nauwkeurigheid, zorgvuldigheid) wordt door $\mathrm{MBO}-\mathrm{BOL}$ gediplomeerden structureel het belangrijkst gevonden voor het goed uitoefenen van hun functie. Basis generieke competenties (schrijfvaardigheid, spreekvaardigheid) worden structureel het minst belangrijk gevonden.

- Ten opzichte van generieke competenties wordt vakkennis steeds belangrijker. Dit geldt voor gediplomeerden van vrijwel alle MBO-BOL niveaus en -sectoren.

- Vakkennis is het belangrijkst voor het goed uitoefenen van de functies van gediplomeerden van MBO-BOL Gezondheidszorg. Deze competentie is het minst belangrijk voor het goed uitoefenen van de functies van gediplomeerden van $\mathrm{MBO}-\mathrm{BOL}$ Economie.
De volgende conclusies kunnen getrokken worden met betrekking tot het bruto uurloon:

- Doordat de gemiddelde bruto uurlonen van MBO-BOL niveau 3 en 4 gediplomeerden langzaam stijgen neemt het verschil met het gemiddelde bruto uurloon van $\mathrm{HBO}$ Bachelor gediplomeerden langzaam af. Het verschil in beloning tussen MBO-BOL niveau 2 en 3 gediplomeerden neemt daardoor echter toe.

- Gediplomeerden van de sector Landbouw hebben doorgaans een relatief laag bruto uurloon. Het verschil in bruto uurlonen van gediplomeerden van verschillende niveaus is binnen deze sector bovendien relatief groot.

- De bruto uurlonen zijn het hoogst voor gediplomeerden van de sector Gezondheidszorg. Hun lonen zijn bovendien langzaam aan het stijgen.

\section{Bijlage $>>$}




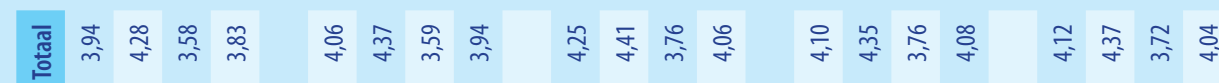

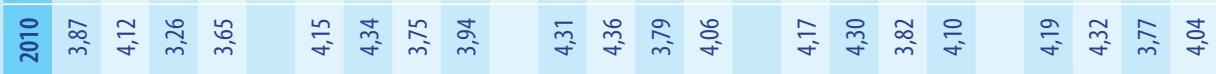

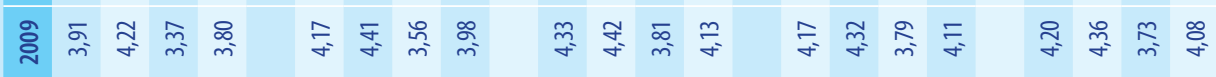

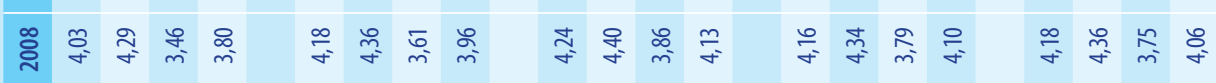

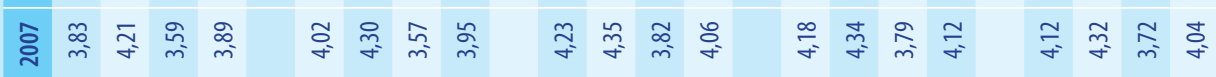

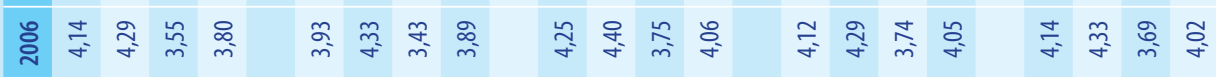

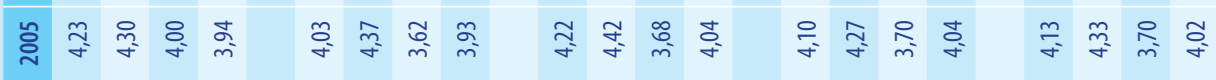

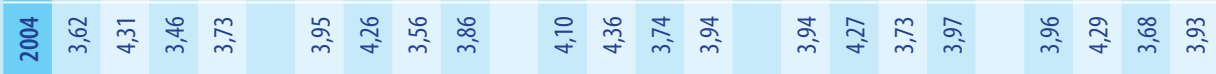

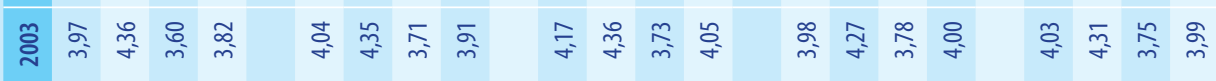

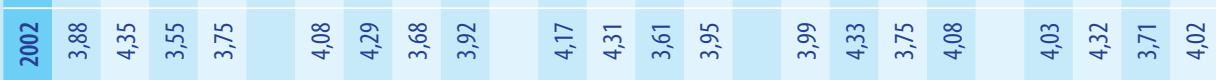

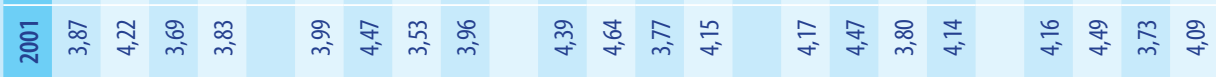
莺

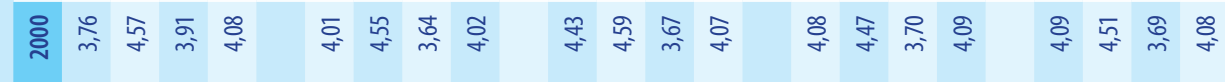

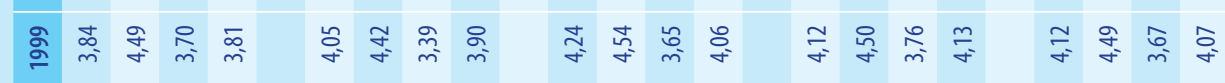

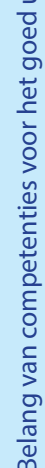

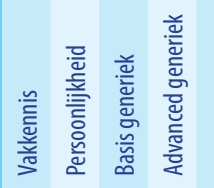

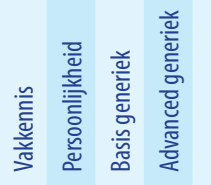

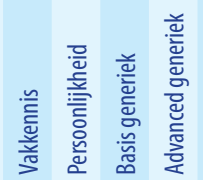

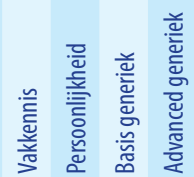

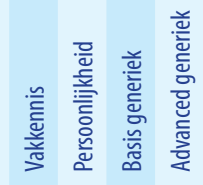


8 Salarissen en competenties van $M B O-B O L$ gediplomeerden: Feiten en cijfers

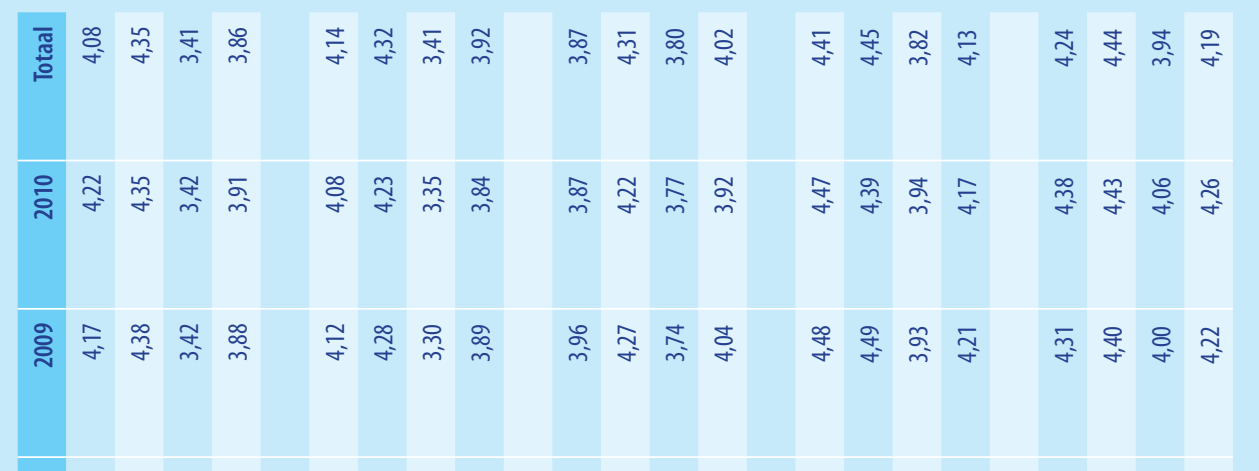

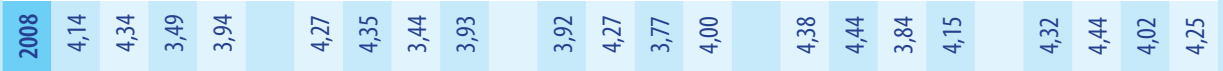

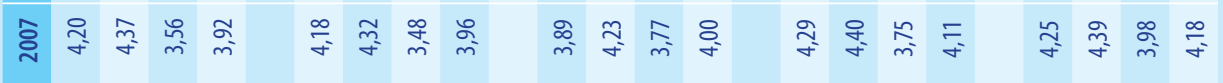

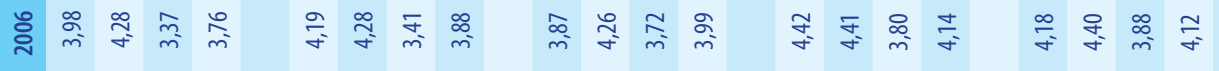

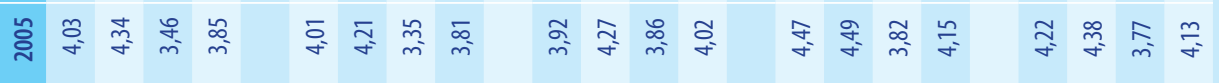

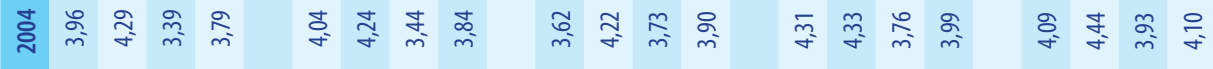

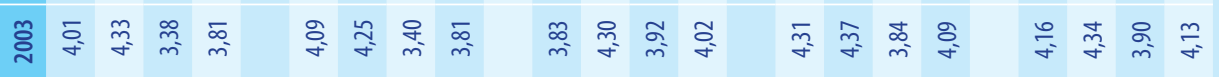

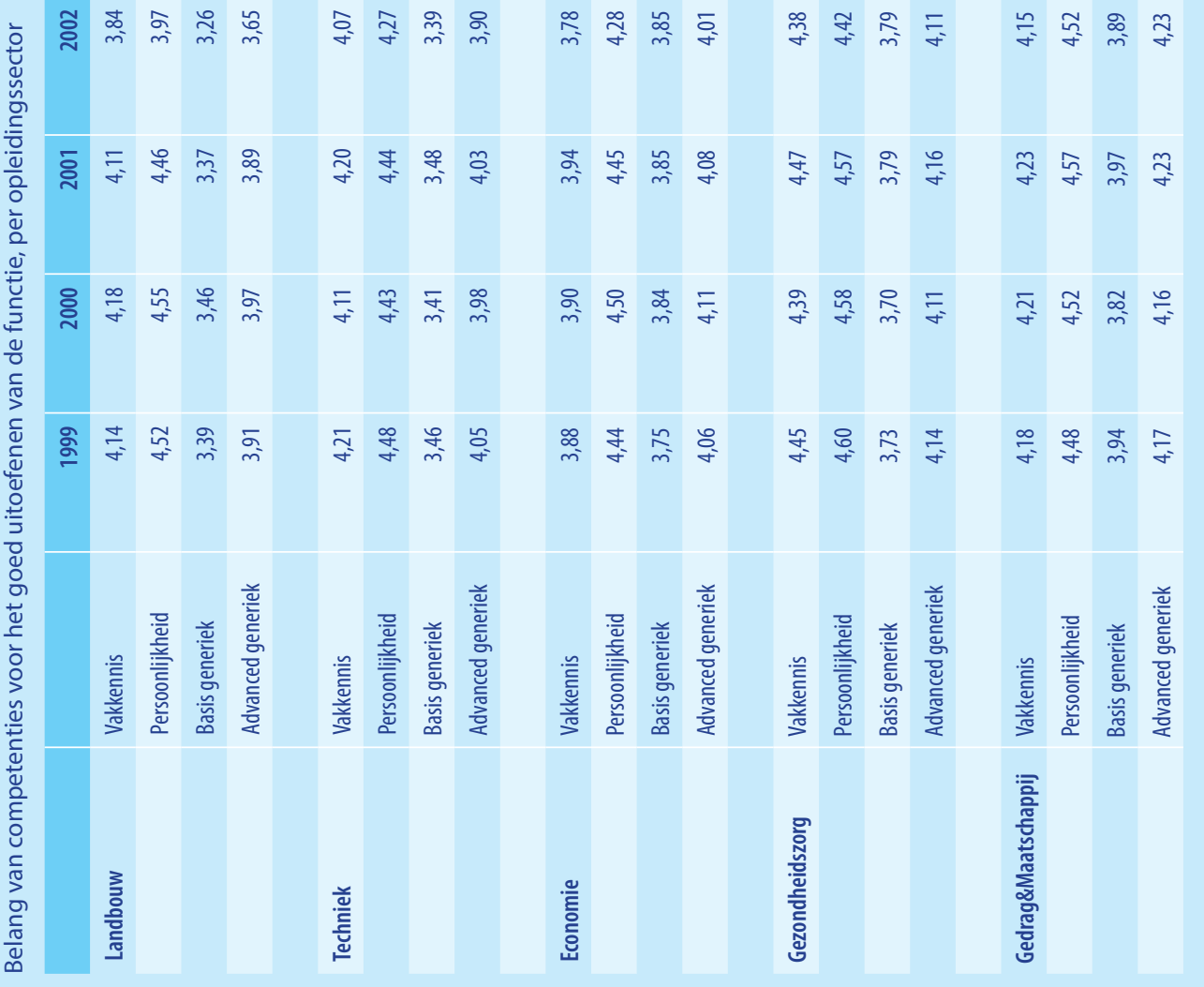




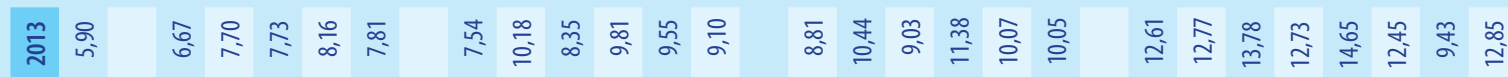

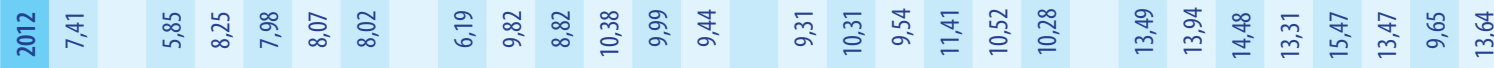

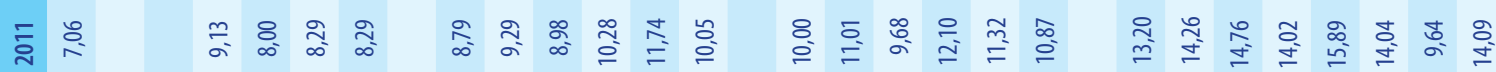

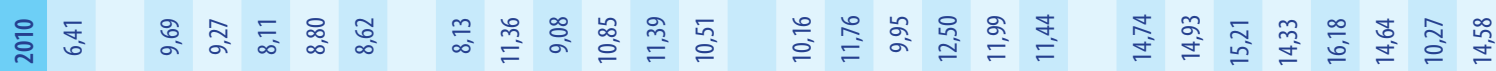

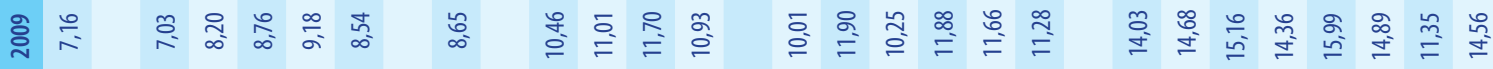

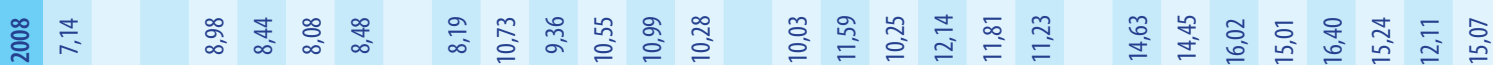

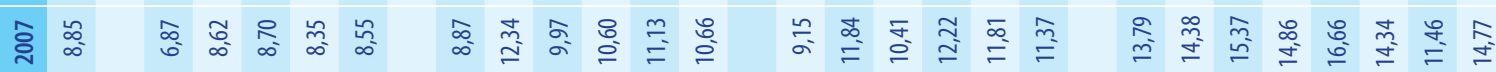

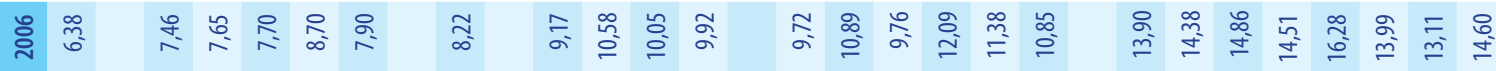

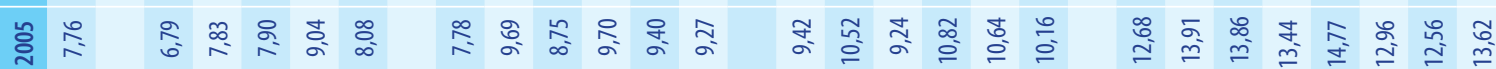

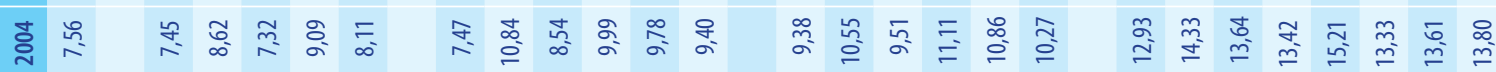

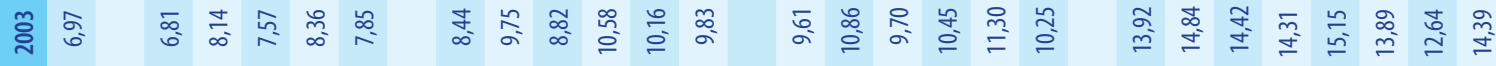

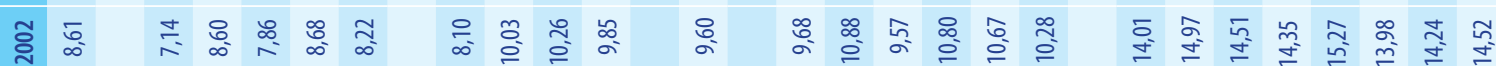

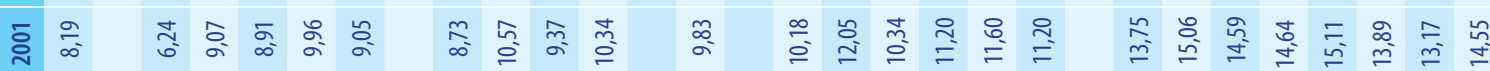

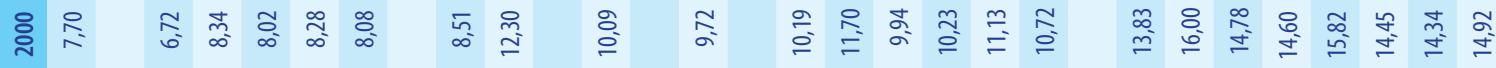

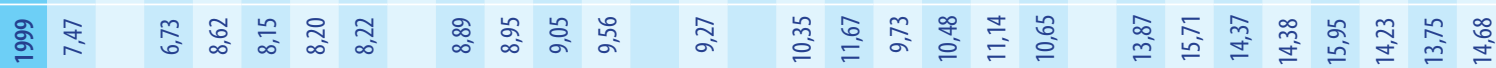

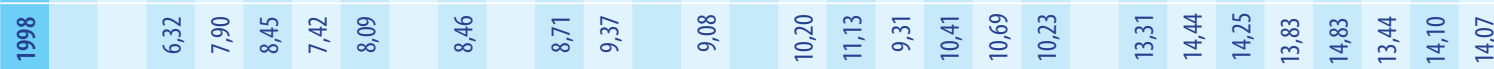

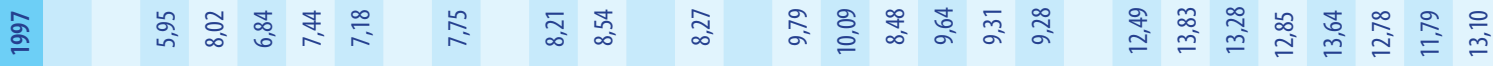

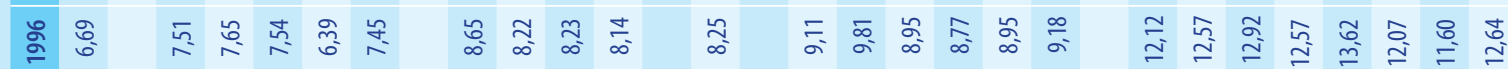
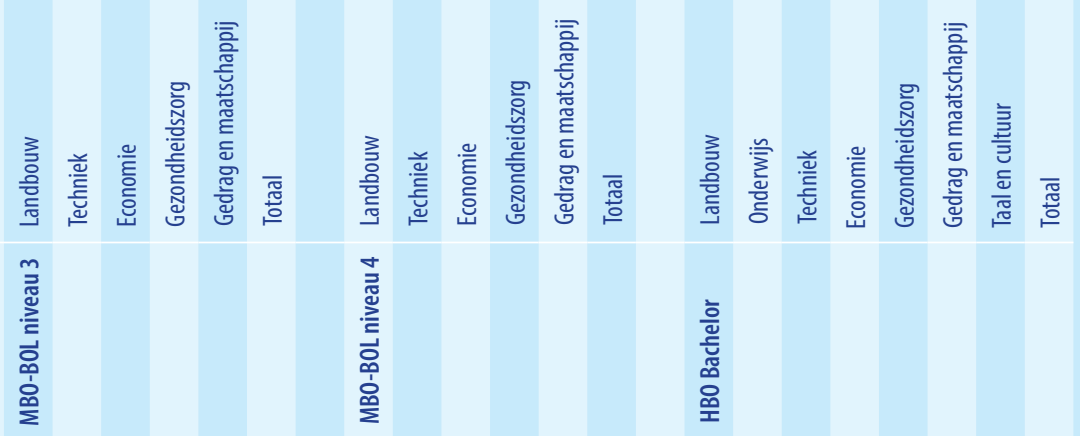
Researchcentrum voor Onderwijs en Arbeidsmarkt

Postbus 616

6200 MD Maastricht

$\mathrm{T}+31433883647$

$\mathrm{F}+31433884914$

secretary-roa-sbe@maastrichtuniversity.n

www.roa.nl

Maastricht University

School of Business and Economics 